\title{
The Effect of Asset Management, Implementation of Internal Control over Financial Reporting (ICOFR), and Organizational Commitment on Quality of Financial Reporting (Survey at Ministry of Marine Affairs of Fisheries Republic Indonesia)
}

\author{
Nine Fitriana ${ }^{1 *}$, Jan Hoesada ${ }^{2}$ \\ Master of Accounting Study Program, Post Graduate Programs, Mercu Buana University
}

DOI: $10.36348 / \mathrm{sb} .2019 . \mathrm{v05i10.001}$

| Received: 20.09.2019 | Accepted: 27.09.2019 | Published: 12.10.2019

*Corresponding author: Nine Fitriana

\section{Abstract}

This study aims to determine the effect of Asset Management, Implementation of Internal Control over Financial Reporting (ICoFR), and Organizational Commitment on quality of financial reporting. This research is a quantitative study with 42 Samples of Work Units of the Ministry of Marine Affairs and Fishery's Head Office, which covers: a) Work Units with their main activities are Ministry of Marine Affairs and Fisheries priority activities, community assistance, or supporting priority activities and community assistance and b) having relatively large budget allocations and financial transactions. Years used as a basis for data collection are 2016 and 2017. This study uses primary data obtained from 70 respondents of the Ministry of Marine Affairs and Fisheries. Smart PLS is used as an analysis tool in this research. The analysis shows that Asset Management has a positive and significant effect over the quality of financial reporting. The implementation of Internal Control over Financial Reporting (ICoFR) has a positive and significant effect on the quality of financial reporting. Organizational Commitment does not significantly influence the quality of financial reporting.

Keywords: Asset management, implementation of ICoFR, organizational commitment, and quality of financial reporting.

Copyright @ 2019: This is an open-access article distributed under the terms of the Creative Commons Attribution license which permits unrestricted use, distribution, and reproduction in any medium for non-commercial use (NonCommercial, or CC-BY-NC) provided the original author and source are credited.

\section{INTRODUCTION}

Results of the audits over the Central Government Financial Statements (LKPP) Year 2016 are based on the results of audits on 87 Financial Statements of State Ministries/ Institutions (LKKL) and one State General Treasurer Financial Report (BUN), as many as 74 LKKL or $84 \%$ get unqualified opinion (WTP). Audit Board of Republic Indonesia (BPK) also gives fair opinion with exceptions (WDP) in 8 LKKLs $(9 \%)$ and opinion disclaimer opinions (TMP) in 6 LKKLs (7\%) (Djanegara, 2017).

Whereas for 2017, as many as 80 LKKLs $(90.9 \%)$ receive WTPs, 6 LKKLs $(6.8 \%)$ receive fair opinions with exceptions (WDP), and 2 LKKLs (2.3\%) receive disclaimer Opinion (TMP). LKKL with WDP opinion namely the Ministry of Defense, the Ministry of Youth and Sports, the National Human Rights Commission (Komnas HAM), the Nuclear Energy
Supervisory Agency (Bapeten), TVRI, and RRI. Meanwhile, for LKKLs with TMP opinion namely the Ministry of Marine Affairs and Fisheries and the Maritime Security Agency [1].

The Disclaimer Opinion obtained by the Ministry of Marine Affairs and Fisheries (KKP) from Audit Board of Republic Indonesia (BPK) was very unexpected, considering the efforts of the Minister of Marine Affairs and Fisheries, Susi Pudjiastuti, have been very maximal in handling maritime issues. The Chairman of BPK RI said that there were still responsibilities that can not be fulfilled in the Ministry of Marine and Fisheries' financial statements, the some accountability process was incomplete, the minutes was incomplete, there was disorderly administration, and there was also the possibility of mistakes in implementing the state asset information system [2]. 
Nine Fitriana \& Jan Hoesada., Sch Bull, Oct 2019; 5(10): 542-550

In terms of asset management according to Hastings [3] is a series of activities related to (1) identifying what assets are needed, (2) identifying funding needs, (3) obtaining assets, (4) providing a logistical and maintenance support system for assets, (5) deleting or renewing assets so that they can effectively and efficiently meet their objectives.

Based on results of Febrianti's research [4], it is known that Bookkeeping, inventory and reports have a simultaneous impact on the quality of financial statements of the Kubu Raya Regency Government. Partially that bookkeeping and reporting have a significant impact on the quality of financial statements and inventory does not have a significant impact on the quality of financial statements of the Local Government of Kubu Raya Regency. Other study by Tangke et al. [5], which studied the Effect of Optimization of Regional Asset Management over the Quality of Financial Statements of the Government of Makassar Municipality shows the results that Optimization of Regional Asset Management has a positive and significant effect on the quality of the Makassar City Government's Financial Statements.

In addition to assets, according to the Commissioner of Audit Board of Republic Indonesia [2] the internal control system is one of the most important things to ensure accountable financial management and allows one financial report to have an unqualified opinion. In the case of internal control according to the concept of Committee of Sponsoring Organizations [6], the process, which is influenced by the entity's board of directors, management and other personnel, designed to provide reasonable assurance related to the achievement of objectives related to operations, reporting and compliance. In public sector organizations or government, internal control is regulated in Government Regulation Number 60 Year 2008 concerning Government Internal Control System (SPIP), namely an integral process on actions and activities carried out continuously by the leaders and all employees to provide adequate confidence in achievement of organizational goals through effective and efficient activities, reliability of financial reporting, securing state assets, and compliance with laws and regulations.

The reliability of financial reporting to government agencies, has been supported by regulations regarding the Internal Control over Financial Reporting (ICoFR) or commonly called Internal Control over Financial Reporting (PIPK). PIPK is a control specifically designed to provide reasonable assurance that the resulting financial statements are reliable and prepared in accordance with government accounting standards.
Research on the effect of the implementation of ICoFR over the quality of financial reporting on government agencies, has not been found by the author so that it refers to the results of research on the implementation of Internal Control Systems (SPI) in general.

Pudjiastuti [7], argued that the awarding of the title of TMP or disclaimer is caused by the negligence of the ministry. Because the Ministry of Marine Affairs and Fisheries was late in reporting the use of its budget to the Audit Board of Republic Indonesia (BPK). In this case there is problem in organizational commitment.

Organizational commitment is defined as the relatively strength of the individual in identifying its involvement in the organization, which is characterized by the acceptance of values and goals of the organization in the willingness to work for the organization and the desire to maintain membership in the organization [8].

Based on the research by Endianto, et al. [9] it noted that there is a positive and significant influence between organizational commitment to the quality of the financial statements of local governments in Bangli Regency.

\section{Literature Review Asset Management}

According to Sugiama [10], based on the management of physical assets, definitively asset management is the science and art of guiding wealth management which covers the process of planning asset needs, obtaining, inventorying, conducting legal audits, assessing, operating, maintaining, renewing or eliminating to transferring assets effectively and efficiently.

Whereas in Government Regulation Number 27 Year 2014 concerning Management of State / Regional Property, management of BMN/D is carried out based on functional principles, legal certainty, transparency, efficiency, accountability, and certainty of value. Management of State / Regional Property covers: a) Planning of Needs and budgeting; b) procurement; c) Use; d) Utilization; e) Security and maintenance; f) Assessment; g) Transfer; h) Destruction; i) Write off; j) administration; and $\mathrm{k}$ ) Guidance, supervision and control.

The results of previous research by Febrianti [4] concerning the Analysis of the Effect of Administration of Fixed Assets on the Quality of Financial Statements of the Kubu Raya District Government is known that bookkeeping, inventory and report has a simultan impact on quality of financial statements of Pemda kabupaten Kubu Raya. In Partial that book keeping and report has a significant impact on 
Nine Fitriana \& Jan Hoesada., Sch Bull, Oct 2019; 5(10): 542-550

quality of financial statements and inventory has no significant impact on quality of financial statements of Pemda Kabupaten Kubu Raya. Other study by Tangke et al. [5], which studied the Effect of Optimization of Regional Asset Management over the Quality of Financial Statements of the Government of Makassar Municipality shows the results that Optimization of Regional Asset Management has a positive and significant effect on the quality of the Makassar City Government's Financial Statements.

\section{Implementation of ICOFR}

Internal Control over financial reporting (ICoFR) or commonly called Internal Control over Financial Reporting (PIPK) is a control specifically designed to provide reasonable assurance that the resulting financial statements are reliable reports and prepared in accordance with government accounting standards (PMK Number 14 /PMK.09/2017).

Whereas internal control according to Government Regulation Number 60 Year 2008 concerning Government Internal Control Systems (SPIP), SPIP is an integral process of actions and activities carried out continuously by the leaders and all employees to provide adequate confidence in the achievement of organizational goals through effective and efficient activities, reliability of financial reporting, securing state assets, and compliance with laws and regulations.

The elements of the internal control system implemented in the government are the control environment, risk assessment, control activities, information and communication, internal control monitoring.

Research on the effect of the implementation of ICoFR over the quality of financial reporting on government agencies, has not been found by the author so that it refers to the results of research on the implementation of Internal Control Systems (SPI) in general.

According to Dianne [11], Implementation of the internal control system of government has positive and significant impact on the quality of financial reporting. Improving control of the internal control system of government become part of a very important role for the quality of financial reporting in local governance. The quality of financial reporting has positive and significant effect to the principles of good governance. Improving the quality of financial reporting major effects in improving the principles of good governance. According to Setiyawati [12], the implementation of the internal control systems simultaneously have a possitive effect on the quality of financial reporting in particular on the local government.

\section{Organizational Commitment}

According to Dise [10], organizational commitment is a commitment created by all individual components in carrying out an organization's operations. This commitment can be realized if individuals in the organization, carry out the rights and obligations of each department/function/ division in accordance with their respective duties and functions in the organization, because the achievement of organizational goals is the work of all members which are collective in nature.

Organizational commitment is built upon the workers' trust on organizational values, the willingness of workers to help to realize the goals of the organization and loyalty to remain a member of the organization. Therefore, organizational commitment will cause a sense of belonging for workers to the organization. If the worker feels his soul is bound to existing organizational values, he would feel happy at work, so that he has responsibility and awareness in running the organization and is motivated to report all activities by carrying out accountability to the public voluntarily including his financial accountability through financial statements [13].

Based on the research by Endianto, et al. [14] it noted that there is a positive and significant influence between organizational commitment to the quality of the financial statements of local governments in Bangli Regency.

\section{Quality of Financial Reporting}

Financial reporting is a financial report that is supplemented with other related information, both directly and indirectly, to information provided by the financial accounting system, such as information about company resources, earnings, current costs, information about company prospects that represent an integral part of the goal to meet an adequate level of disclosure [15].

In Government Regulation No. 71 Year 2010 concerning Government Accounting Standards, the qualitative characteristics of financial statements are normative measures that need to be materialized in accounting information so that they can meet their objectives. The following four characteristics are the normative prerequisites required for government financial reports to meet the desired quality: 1) being relevant, 2) reliable, 3) comparable, 4) understandable.

Based on the theory and description above and supported by the available facts, the author would like to investigate further on "The Effect of Asset Management, Implementation of Internal Control over Financial Reporting (ICoFR), and Organizational Commitment over the Quality of Financial Reporting (Survey at Ministry of Marine Affairs and Fisheries Republic Indonesia ). 
Nine Fitriana \& Jan Hoesada., Sch Bull, Oct 2019; 5(10): 542-550

\section{Framework}

Linkage of asset management, implementation of Internal Control over Financial Reporting (ICoFR), and organizational commitment on the quality of financial reporting can be described as follows:

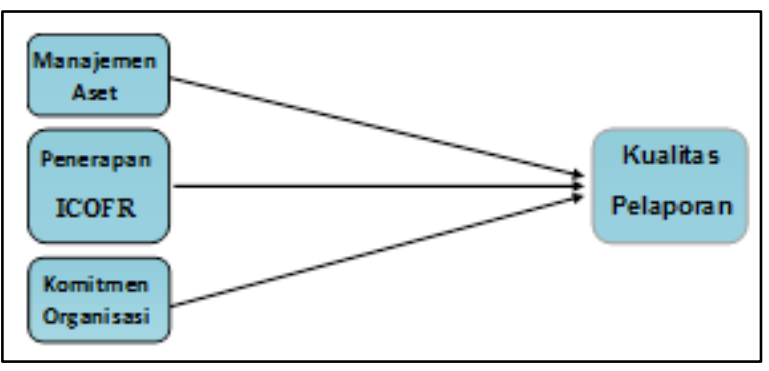

Fig-1: Framework

\section{Hypotheses}

The hypotheses in this study are as follows:

H1 : Asset management influences the quality of financial reporting.

$\mathrm{H} 2$ : Implementation of ICoFR influences the quality of financial reporting.

H3 : Organizational commitment influences the quality of financial reporting.

\section{RESEARCH METHOD}

The research method used is causal quantitative research since it aims to examine hypotheses about the effect. Based on the time this study is cross sectional, namely research conducted at a certain time period to collect data in order to find answers to research questions.

In this study, the research is designed to identify and describe how asset management, the implementation of internal control over financial reporting, and organizational commitment have an effect on the quality of financial reporting.

The collection of research samples were 42 Ministry of Marine and Fisheries' Headquarters Work Units out of a total population of 408 Work Units, because the Work Units have the main activities of the Ministry of Marine Affairs and Fisheries' priority activities, community assistance, and supporting priority activities and community assistance as well as having budget allocations and financial transactions that take place relatively huge.

Data collection in this study was carried out using a questionnaire distributed directly to respondents and documentation. Assessment is performed by descriptive analysis, validity test, reliability test, which is processed with the smart PLS specification model.

Significant or insignificant criteria of the effect of a construct (exogenous) on other constructs (endogenous) is determined by identifying the path coefficient of a construct against another construct $(\mathrm{t}-$ count), then comparing the path coefficient with the ttable of (1.9966). T-table calculation was obtained using $\alpha=5 \%$ with $\mathrm{CI}=95 \%$.

Based on the coefficients of path parameter, the following equation is formed:

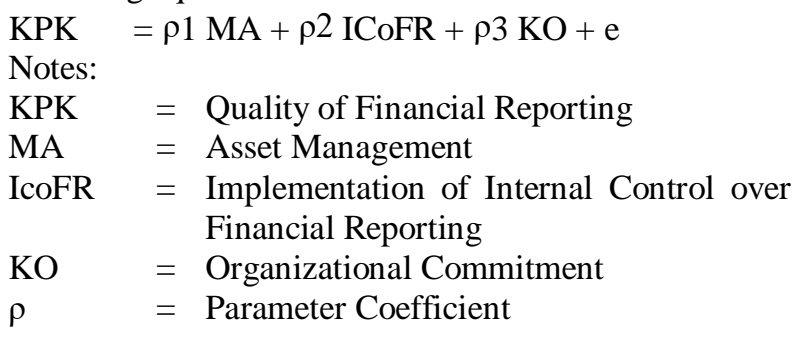

The hypothesis testing of the structure about the effects of variables $\mathrm{X}_{1}, \mathrm{X}_{2}$, and $\mathrm{X}_{3}$ on the variable $\mathrm{Y}$ can be explained as follows: Path coefficient pyx 1 describes the magnitude of effect expected from Asset Management $\left(\mathrm{X}_{1}\right)$ on the quality of financial statements (Y). The path coefficient pyx2 describes the effect of the implementation of ICOFR $\left(\mathrm{X}_{2}\right)$ on the quality of financial statements $(Y)$. The path coefficient $\rho y x 3$ describes the magnitude of the effect of organizational commitment $\left(\mathrm{X}_{3}\right)$ on the quality of financial statements (Y).

\section{RESULTS AND DISCUSSION Description of Research Object}

Primary data in this study were obtained from distributing questionnaires to 84 respondents in 42 Central Work Units during the period 21 June through 3 July 2019. Respondents who filled out the questionnaires through Google form were 34 respondents and questionnaires were collected by picking up directly to the analysis units of 36 respondents, bringing the total return of the questionnaire to 70 respondents or $83.33 \%$.

\section{Result of Validity Test}

Validity test is conducted to determine whether the research questionnaire is valid or not. A statement/ research variable is declared to be valid if it has a loading factor above 0.7 with the construct being tested [16].

Based on the results of the validity test through the smart PLS application, it is identified that from 70 indicators there are 7 indicators that are invalid because they have a loading factor below 0.7 , then the indicators are eliminated and a re-validity test is done with the results of all indicators declared to be valid.

\section{RESULTS OF RELIABILITY TEST}

Reliability testing is conducted to measure the level of reliability of research's measuring instruments with the criteria of composite reliability and Cronbach alpha. A construct is said to be reliable if the composite 
Nine Fitriana \& Jan Hoesada., Sch Bull, Oct 2019; 5(10): 542-550

reliability and Cronbach alpha values are more than 0.70 .

The reliability test results show that for the variable the Effect of Asset Management, the Implementation of Internal Control on Financial Reporting (ICoFR), and Organizational Commitment, and Quality of Financial Reporting have composite reliability above 0.7 , so it can be concluded that the indicators used in each variable has a good reliability or is able to measure its construction.

\section{Results of Goodness of Fit Test of Structural Model}

Goodness of Fit Test of Structural Model is measured using predictive-relevance $\left(\mathrm{Q}^{2}\right)$ and values of $\mathrm{R}$-Squared $\left(\mathrm{R}^{2}\right)$. The value of $\mathrm{R}^{2}$ is the coefficient of determination which is part of the total variation in the dependent variables which are explained by variations in the independent variable.

Table-1: Results of $Q^{2}$ and $R^{2}$ Tests

\begin{tabular}{|l|c|c|c|}
\hline \multicolumn{1}{|c|}{ Variables } & R Square & $\begin{array}{c}\text { R Square } \\
\text { Adjusted }\end{array}$ & $\mathbf{Q}^{\mathbf{2}}$ \\
\hline $\begin{array}{l}\text { Quality of } \\
\text { Financial } \\
\text { Reporting }\end{array}$ & 0,702 & 0,688 & 0,493 \\
\hline
\end{tabular}

Source: Output SmartPLS

Based on the coefficient of determination in the table above, the $\mathrm{R}^{2}$ value for the variable of quality of financial reporting is 0.702 which means that the value indicates that the variable of Financial Reporting Quality that can be explained by the variable of construct the Effect of Asset Management, Implementation of ICoFR, and Organizational Commitment is $70.20 \%$, while $29.80 \%$ is explained by other variables not tested.

The value of $\mathrm{Q}$ Square or predictive relevance for the structural model in this study is 0.493 or $49.3 \%$ meaning the model is able to explain the phenomenon of financial reporting quality associated with several variables, namely Asset Management, Implementation of ICo FR, and Organizational Commitment. Therefore, the model can be said to be good or the model has a good predictive value. In the end the model can be used for hypothesis testing.

\section{Outcome of Hypothesis Test}

To test the hypotheses in this study, partial tstatistic values are used for each path of effect. The following is a path diagram for testing hypotheses:

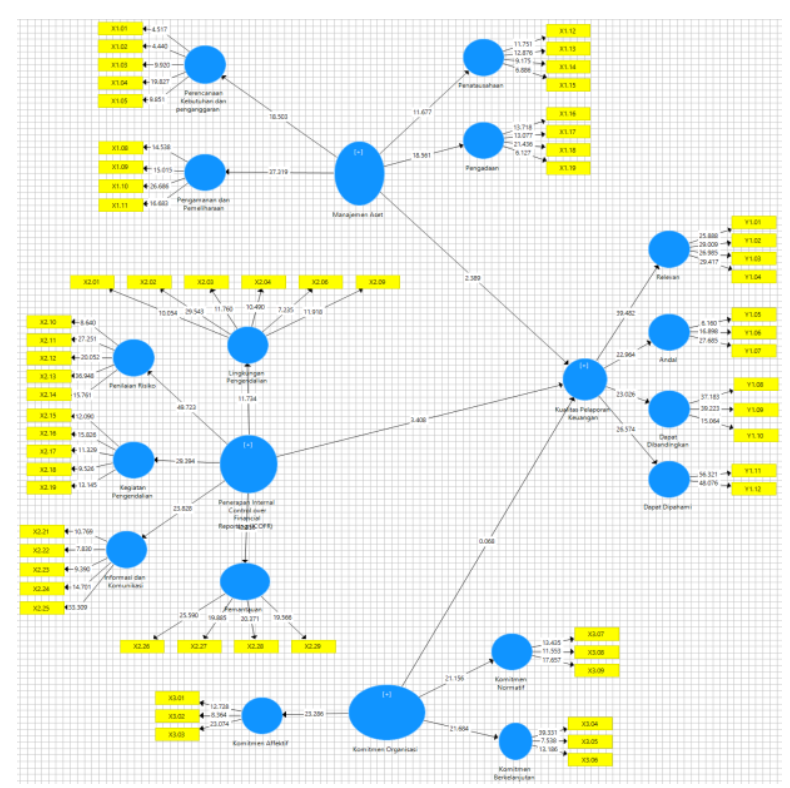

Fig-2: Path Diagram of Hypothesis Testing

Based on the diagram path of hypothesis testing above, all dimensions on each variable have a $\mathrm{t}_{\text {count }}$ greater than $\mathrm{t}_{\text {table }}(1.9966)$ at a significance level of 0.05 , so that the dimensions are able to measure each construct. Meanwhile, to test the relationship among the variables (hypothesis testing), the t-statistic value of the smartPLS output is compared with the t-table value.

\section{Hypothesis Testing the Effect of Asset Management on the Quality of Financial Reporting}

Testing of path coefficients on variable of Effect of Asset Management as described in Table 2 below:

Table-2: Values of Path Coefficients

\begin{tabular}{|c|c|c|c|}
\hline Variables & $\begin{array}{l}\text { Original Sample } \\
(\mathbf{O})\end{array}$ & $\begin{array}{l}\text { T Statistic } \\
\text { (O/STDEV) }\end{array}$ & $\begin{array}{c}\mathbf{P} \\
\text { Values }\end{array}$ \\
\hline $\begin{array}{l}\text { Effect of Asset Management }>\text { Quality of } \\
\text { Financial Reporting }\end{array}$ & 0.330 & 2.389 & 0.017 \\
\hline
\end{tabular}

Source: Output of SmartPLS

Based on Table 2, the coefficient of path parameter obtained from the Effect of Asset Management is 0.330 with a $t_{\text {statistic }}$ value $=2.38>$ 1.9966 at the significance level $\alpha=0.05(5 \%)$ which indicates that there is a positive and significant effect between the Effect of Asset Management on the quality of financial reporting. Value of 0.330 on the parameter coefficient means that the better the asset management, the better the quality of financial reporting, and this supports the first research hypothesis, where there is a positive and significant effect between asset management and the quality of financial reporting. 


\section{Hypothesis Testing of the Effect of ICoFR Implementation on Quality of Financial Reporting}

The path coefficients testing of the variable of ICoFR Implementation as described in Table 3 below:

Table-3: Values of Path Coefficients

\begin{tabular}{|c|r|r|r|}
\hline Variable & Original Sample (O) & T Statistic (O/STDEV) & P Values \\
\hline IcoFR Implementation > Quality of Financial Reporting & 0.543 & 0.408 & 0.001 \\
\hline
\end{tabular}

Based on Table 3, the coefficient of path parameter obtained from the effect of the IcoFR Implementation is 0.543 with a statistical value = $3.408>1.9966$ at a significance level $\alpha=0.05$ (5\%) which indicates that there is a positive and significant effect between the implementation of ICoFR on the quality of financial reporting. The value of 0.543 on the parameter coefficient means that the better the implementation of ICoFR, the better the quality of financial reporting, and this supports the second research hypothesis, where there is a positive and significant effect between the implementation of ICoFR with the quality of financial reporting.

Hypothesis Testing the Effect of Organizational Commitment on Quality of Financial Reporting

Testing path coefficients of variable Organizational Commitment as described in Table 4. Below:

Table-4: Value of Path Coefficients

\begin{tabular}{|l|c|c|c|}
\hline \multicolumn{1}{|c|}{ Variable } & $\begin{array}{c}\text { Original Sample } \\
(\mathbf{O})\end{array}$ & $\begin{array}{c}\text { T Statistic } \\
\text { (O/STDEV) }\end{array}$ & P Values \\
\hline $\begin{array}{l}\text { Organizational Commitment > Quality of } \\
\text { Financial Reporting }\end{array}$ & 0.007 & 0.068 & 0.946 \\
\hline
\end{tabular}

Source: Output Smart PLS

Based on Table 4, the coefficient of path parameter obtained from the Effect of Organizational Commitment is 0.007 with value of $t_{\text {statistics }}=0.068$ $<1.9966$ at the significance level $\alpha=0.05$ (5\%) which indicate that there is no significant effect between the Effect of Organizational Commitment on quality of financial reporting. The value of 0.007 on the parameter coefficient means that the better the Organizational Commitment, the quality of financial reporting is not getting better, and this turns down the third research hypothesis, where there is a positive and significant effect between Organizational Commitment and the quality of financial reporting.

Based on the coefficients of path parameter obtained in Tables 2, 3, and 4 as well as the description above, then the equation model of the research formed can be explained with the model proposed in this study:

$$
\mathrm{KPK}=0.330 \mathrm{MA}+0.543 \mathrm{ICoFR}+0.007 \mathrm{KO}+\mathrm{e}
$$

Notes:

$$
\begin{array}{ll}
\text { KPK } & \text { Quality of Financial Reporting } \\
\text { MA } & =\text { Asset Management } \\
\text { ICoFR } & =\text { Implementation of Internal Control on } \\
& \text { Financial Reporting } \\
\text { KO } & =\text { Organizational Commitment } \\
\mathrm{E} & =\text { Error }
\end{array}
$$

In this research model, the effect of asset management on the quality of financial reporting has a regression coefficient of 0.330 meaning that when asset management increases (increases by 1) then the quality of financial reporting will increase by 0.330 . Similarly, the effect of the implementation of ICo FR on the quality of financial reporting has a regression coefficient of 0.543 , meaning that when the implementation of ICoFR increases (increases by 1) then the quality of financial reporting will increase by 0.543 .

\section{DISCUSSION}

\section{The Effect of Asset Management on the Quality of Financial Reporting}

Based on statistical tests and significance it is identified that there is a positive and significant effect between the Effect of Asset Management on the quality of financial reporting. The results of this study are in line with Febrianti [4] and Tangke, et al. [5] who argues that asset management has a significant effect on the quality of financial reporting. Likewise with Sisdianto and Nengsih's (2017) research which concluded that regional asset management also has a positive and significant direction on the quality of the Regional Government's financial statements and that regional asset management has a major role in determining the quality of financial statements that will be presented. Asset management in this study takes the form of planning the needs and budgeting, procurement, security and maintenance, and administration.

The results of BPK's audits of the Ministry of Marine Affairs and Fisheries' Financial Statements on the 2016 and 2017, based on first semester of 2017 of Oversight Summary Results (IHP) and first semester of 
Nine Fitriana \& Jan Hoesada., Sch Bull, Oct 2019; 5(10): 542-550

2018 of IHP, indicate that the Ministry of Marine Affairs and Fisheries obtained a disclaimer opinion due to the Ministry of Marine Affairs and Fishery's poor asset management.

Likewise with Sisdianto and Nengsih's (2017) research which concluded that regional asset management also has a positive and significant direction on the quality of the Regional Government's financial statements and that regional asset management has a major role in determining the quality of financial statements that will be presented.

Based on the results of the study and IHP Semester I Year 2017 and IHP Semester I Year 2018 of Supreme Audit Agency, it can be concluded that there is a significant effect between the Effect of Asset Management on the quality of financial reporting.

\section{Effect of ICoFR Implementation on Quality of Financial Reporting}

Based on statistical tests and significance it is identified that there is a positive and significant effect between the implementation of ICoFR with the quality of financial reporting. These results are in line with the study of the effect of the Internal Control System / SPI in general on the quality of financial reports by Kesuma, et al. [14], Dianne [11], and Kasim [17] who argue that a good implementation of SPI will produce good quality financial information as well.

The phenomenon of the low quality of the Ministry of Marine Affairs and Fisheries' financial reporting Years 2016 and 2017 based on IHP Semester I Year 2017 and IHP Semester I Year 2018, was answered by the non-optimal implementation of ICoFR/PIPK within the Ministry of Marine Affairs and Fisheries.

Based on the results of BPK's audit on IHP Semester I Year 2017 and IHP Semester I Year 2018, it was found that there were problems with weaknesses in the Internal Control System/SPI and non-compliance with regulatory provisions. The weaknesses of the SPI consist of weaknesses in the accounting and reporting control system, the control system for the revenue and expenditure budget performance, and the internal control structure.

Based on an analysis of the answers to this research questionnaire, the implementation of ICoFR can be carried out through:

\section{- Control environment}

- Risk Assessment

- Control Activities

- Information and Communication

- Monitoring
Based on the discussion it can be concluded that there is a positive and significant effect on the implementation of ICoFR with the quality of financial reporting.

\section{Organizational Commitment on Quality of Financial Reporting}

Based on statistical tests and significance it is identified that there is a positive but not significant effect between organizational commitment and the quality of financial reporting. This is in accordance with the results of Septarini and Papilaya's research [18] on the interaction of organizational commitment to the factors that influence the quality of local government financial statements, which explains that organizational commitment strengthens the relationship of Human Resources competencies to the Quality of Financial Statements, and concludes that organizational commitment moderates the relationship between competencies of human resources to the quality of local government financial statements.

The success of preparing a quality financial report is not only determined by asset management and ICoFR implementation. The factor of organizational commitment of individuals involved in the preparation of financial statements also determines the results obtained. Organizational commitment will lead to employees' sense of belonging to the organization, thereby raising responsibility and awareness in running the organization and is motivated to achieve organizational goals.

In this study, organizational commitment does not significantly influence the quality of financial statements because respondents (the State Civil Apparatus at the central work unit of the Ministry of Maritime and Fisheries) tend to hold the ethics of rules that are enforced formally and informally to government agencies. The formal employment ethics in the form of a law governing civil servants is Law No. 5 Year 2015 concerning State Civil Apparatus (ASN). The law is used as a basis for regulating ASN in providing services to the communities, including in survey services conducted by the author. The respondents have eastern character, how ethics of service to the community, how to build a culture of shame, the existence of solidarity, is an eastern culture that is inherent in the respondent. In addition, the connection with religion is the basis of faith, how to help others, how to respect people, how to foster empathy, sympathy, and so forth, these have been the character of respondents, so that organizational commitment should be owned by the respondents. As a result, organizational commitment does not significantly influence the quality of financial reporting.

CONCLUSION AND RECOMMENDATIONS Conclusion 
Nine Fitriana \& Jan Hoesada., Sch Bull, Oct 2019; 5(10): 542-550

Based on the formulation of the problem, the hypothesis testing, and the discussion in the previous chapter, it is concluded that:

- Asset Management has a positive and significant effect on the quality of financial reporting. Improvement of the dimensions of asset management in the form of planning of the needs and budgeting, procurement, security and maintenance, and administration of assets in an agency can improve the quality of financial reporting.

- Implementation of ICoFR has a positive and significant effect on the quality of financial reporting. The implementation of ICoFR elements in the forms of a control environment, risk assessment, control activities, information and communication, and monitoring at an agency can improve the quality of financial reporting.

- Organizational Commitment has no significant effect on the quality of financial reporting. Improvements in dimensions of organizational commitment in the forms of affective, sustainable, and normative commitment to an agency do not significantly improve the quality of financial reporting.

\section{RECOMMENDATIONS}

Based on the discussion and conclusions above, the author provides recommendations to the Head of the Work Unit of the Ministry of Marine Affairs and Fisheries as follows:

- Improving asset management at the stage of planning the needs and budgeting, procurement, security and maintenance, and administration.

- Improving the Implementation of ICo FR, among them the control environment, risk assessment, control activities, information and communication, as well as monitoring of each types of activities at the Ministry of Marine Affairs and Fisheries.

- For the next researches, it is expected that the researchers will examine the effect of the implementation of ICOFR on the quality of financial reporting based on the Minister of Finance Regulation No. 17 of 2019 with a larger number of samples and respondents. In addition, the variable of organizational commitment needs to be tested for its effect on the quality of financial statements in non-governmental organizations.

\section{REFFERENCE}

1. Akbar, B. (2018). BPK Beri Opini WTP Laporan Keuangan Pemerintah Pusat 2017. Diakses pada 31 Mei 2018 dari World Wide Web: https://finance.detik.com/berita-ekonomi-bisnis/d4046610/bpk-beri-opini-wtp-laporan-keuanganpemerintah-pusat-2017.

2. Djanegara, M.S. (2017a). BPK Beri Opini Wajar Tanpa Pengecualian atas LKPP 2016. Diakses pada 26 Mei 2018 dari World Wide Web: http://www.bpk.go.id/news/bpk-beri-opini-wajartanpa-pengecualian-atas-lkpp-2016.

3. Lubis, A.I. (2010). Akuntansi Keperilakuan. Edisi dua. Salemba empat: Jakarta.

4. Febrianti, S. (2016). Analisis Pengaruh Penatausahaan Aset Tetap Terhadap Kualitas Laporan Keuangan Pemerintah Daerah Kabupaten Kubu Raya. Jurnal Ekonomi Manajemen, 10(1).

5. Tangke, J. G., Halim, H., \& Lucita, G. (2015). Pengaruh Optimalisasi Manajemen Aset Daerah Terhadap Kualitas Laporan Keuangan Pemerintah Kota Makassar. Jurnal Administrasi Negara, 21(1), $1-5$.

6. Sisdianto, Ersi. Dan Nengsih (2017) Analisis Pengaruh Kinerja Keuangan, Realisasi Belanja Modal, dan Pengelolaan Manajemen Aset Daerah terhadap Kualitas Laporan Keuangan (Survey pada Pemerintah Daerah Kota Bengkulu), Provita, vol. 10. No.1, April 2017.

7. COSO. (2013). Internal Control - Integrated Framework: Executive Summary. Durham, North Carolina.

8. Robbins, S. P. Dan Timothy A. J. (2015). Perilaku Organisasi. Edisi 16. Jakarta: Salemba Empat.

9. Djanegara, M.S. (2017b). BPK Jelaskan Pemberian Opini Disclaimer ke Kementerian Kelautan. Diakses Pada 26 Mei 2018 dari World Wide Web: https://bisnis.tempo.co/read/877735/bpk-jelaskanpemberian-opini-disclaimer-ke-kementeriankelautan.

10. Sugiama, A. G. (2012). Handout Penilaian Aset.

11. Afiah, N. N., \& Azwari, P. C. (2015). The effect of the implementation of government internal control system (GICS) on the quality of financial reporting of the local government and its impact on the principles of good governance: A research in district, city, and provincial government in South Sumatera. Procedia-Social and Behavioral Sciences, 211, 811-818.

12. Setiyawati, H. (2013). The effect of Internal Accountants' Competence, Managers' Commitment to Organizations and the Implementation of the Internal Control System on the Quality of Financial Reporting. International Journal of Business and Management Invention, 2(11), 19-27.

13. Kreitner, R., \& Kinicki, A. (2013). Perilaku Organisasi. Terjemahan Erly Suandy, Edisi Pertama, Jakarta: Salemba Empat

14. Kesuma, P. K., \& Choirul Anwar, D. (2017). Pengaruh Good Governance, Penerapan Standar Akuntansi Pemerintah, Sistem Pengendalian Internal Pemerintah Dan Kompetensi Aparatur Pemerintah Terhadap Kualitas Laporan Keuangan Pemerintah Pada Satuan Kerja Kementerian Pariwisata. Jurnal Ilmiah WIDYA Ekonomika, 1(2).

15. Yadiati, W. (2007). Teori Akuntansi Suatu Pengantar. Jakarta: Kencana. 
16. Wati, L. N. (2017). Metodologi Penelitian Terapan, Aplikasi SPSS, EVIEWS, Smart PLS dan Amos. Bandung.

17. Kasim, E. Y. (2015). Effect of government accountants competency and implementation of internal control to the quality of government financial reporting. International Journal of Business, Economics and Law, 8(1), 97-105.

18. Septarini, D. F., \& Papilaya, F. (2016). Interaksi Komitmen Organisasi Terhadap Faktor-faktor yang Mempengaruhi Kualitas Laporan Keuangan Pemerintah Daerah. Jurnal Ilmu Ekonomi \& Sosial Unmus, 7(2), 100-116. 